\title{
Organisation of safety measures in an Alpine World Junior Championship
}

\author{
K A Bergstrøm, A Bergstrøm, A Ekeland
}

\begin{abstract}
Objectives-To study the implementation of skiing safety during the Alpine World Junior Championship of 1995.

Methods-A map of the area was made with descriptions of the slopes and all its facilities and the security measures along the course. The number of competitors who started and any injuries reported were recorded in a questionnaire.

Results-A total of 452 girls and 546 boys started in the different races. Only four injuries were recorded, all in girls. The overall injury rate was 4 per 1000 runs. An injury rate of 8.3 per 1000 runs was recorded in the downhill. One skier had a possibly severe injury $($ ISS $=14$ ) in the downhill; the rest of the injuries were minor $($ ISS $=1)$. The mean ISS was 4.3 and the total ISS was 17 .

Conclusions-A significantly higher injury rate was recorded for young female than young male racers. The injury rate was significantly higher in downhill than the other alpine disciplines in the Alpine World Junior Championship. The injury rate was not significantly different from that recorded one year previously for Olympic racers, and juniors therefore need the same safety measures as Olympic racers.
\end{abstract}

(Br F Sports Med 2001;35:321-324)

Keywords: skiing; age; sex; downhill; competition

The Alpine World Junior Championship was arranged in Bavallen, Voss, Norway in 1995. We attempted to make the safety in this championship as close as possible to that of the alpine disciplines of the Winter Olympic Games in Kvitfjell/Hafjell in Lillehammer in 1994.

Shealy and Ettlinger ${ }^{1}$ reported a higher injury rate in female recreational skiers than in their male counterparts, but not after adjustment for skiing ability. Blitzer et $a l^{2}$ and Ekeland et $a l^{\beta}$ found that boys and girls between 15 and 19 years of age are the most commonly injured recreational skiers. Ellman et $a l^{4}$ reported a much higher incidence of serious knee injuries in female than male ski racers. More female than male alpine Olympic racers had suffered previous skiing injuries. ${ }^{5}$

The purpose of this study was to gain additional information about junior ski competitors by asking the following questions. Do they have many skiing injuries and are they severe? Are there sex differences when the conditions are the same? Do they need the same safety measures and rescue services as Olympic racers?

\section{Methods}

Safety was organised according to the International Federation of Skiing (FIS) Medical Guide, ${ }^{6}$ FIS Safety at Alpine Competitions, ${ }^{7}$ the International Competition Rules (ICR), and the Rules for the Organisation of World Junior Championships in the Alpine Disciplines. The slopes were homologated by the FIS Committee for Alpine Courses. The Medical and Rescue Services were homologated by the FIS Medical Committee. The junior competitors were 15-19 years of age. A medical certification of sex was required from all female participants. ${ }^{6}$ Anti-doping control was compulsory ${ }^{6}$ and performed by the Norwegian Sports Federation.

Safety measures were divided into three parts.

(1) Precompetition: planning before the race. The organisation committee paid special attention to the racer, the team work support, the slopes, and the security measures along the slopes as specified on the map (fig 1). The weather forecast provided important information, and a meteogram (numerical weather prediction model) was used for everyday planning.

(2) Percompetition: security measures taken during the competition and medical and rescue facilities on alert. Communication was organised according to safety instructions, with the race chief as the key person. The racers were well equipped, and a representative from the International Federation of Skiing had the ski suits sealed. Side slippers were used between each racer to keep the conditions on the slopes as good as possible. Small branches were used to limit the course and straw material to improve the visibility. Competitors could be stopped by waving of a yellow flag at jury positions 4 and 7 (fig 1). A-nets were $4 \mathrm{~m}$ high with $1.5 \mathrm{~m}$ of gliding surface along the bottom secured with polyethylene ropes. B-nets were 2 $\mathrm{m}$ high with plastic poles separated by $1 \mathrm{~m}$. The B-nets were placed in double or triple rows at dangerous sites. Start times were always selected with reference to the meteogram.

(3) After an injury: medical and rescue services after an injury had occurred. The number of competitors who started and the race completion rate were recorded. Communication between the rescue teams and the race chief was good. When a fall was observed to have occurred, the skier was not examined until the jury had cleared the course and temporarily stopped the race. Three rescue teams with 


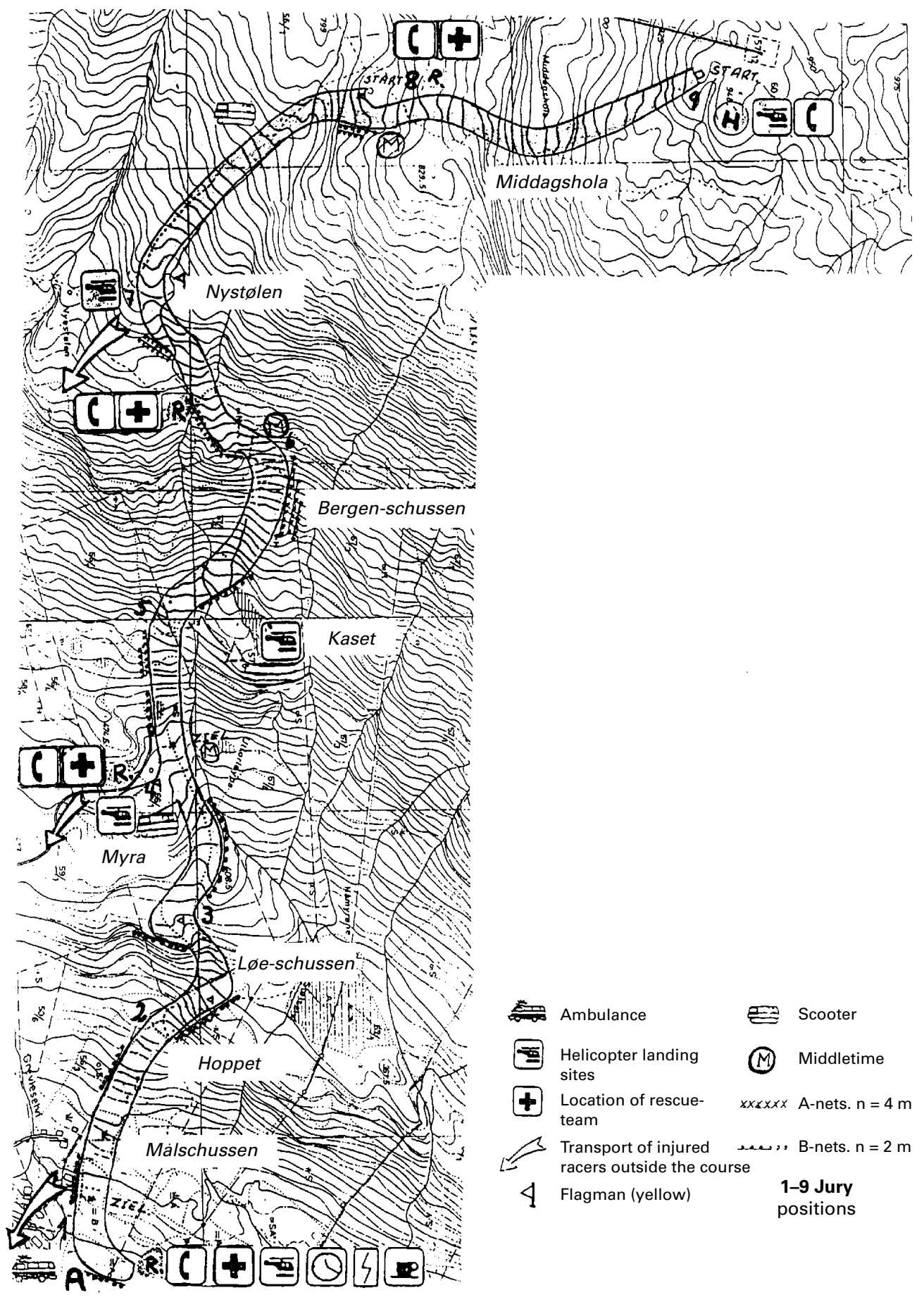

Figure 1 Map showing safety measures on the downhill course of the Alpine World Funior Championship.

sledges were on standby at jury positions 4,7 , and 8 (fig 1). Each team included one doctor, two paramedics, a resuscitation unit, fracture immobilisation equipment, and a vacuum madras. ${ }^{6}$ In the finishing area, there was a helicopter with an anaesthesiologist, an ambulance, and a tent with military medical equipment ready to deal with any injuries.

A questionnaire was designed to record any injury during training and competition in all disciplines. The injury rate and injury severity score (ISS) were than calculated..$^{8-11}$ An injury was defined as one that required the skier to be transported or treated by the medical team, with ISS from 1 to 75 .

STATISTICAL ANALYSIS

The results are presented as percentage of the skier population, as injury rates, and as ISS. Differences were evaluated by Student's $t$ test or $\chi^{2}$ test, and considered significant when $\mathrm{p} \leqslant 0.05$.

\section{Results}

A total of 998 runs ( 452 by girls and 546 by boys) were made through the different alpine 
Table 1 Injuries and injury severity score (ISS) in Alpine World funior Championship 1995

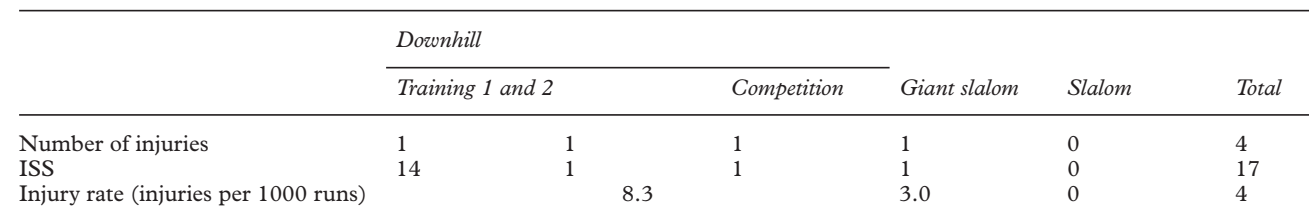

Table 2 Number of runs in all courses and race completion rates in Alpine World funior Championship 1995

\begin{tabular}{|c|c|c|c|c|}
\hline & Downhill & Giant slalom & Slalom & Total \\
\hline \multicolumn{5}{|c|}{ Number of runs started } \\
\hline Boys & $197(66)$ & $185(100)$ & $164(96)$ & 546 \\
\hline Girls & $165(55)$ & $143(77)$ & $144(79)$ & 452 \\
\hline \multicolumn{5}{|c|}{ Number of runs completed } \\
\hline Boys & 193 & 66 & 52 & 311 \\
\hline Girls & 156 & 55 & 51 & 262 \\
\hline \multicolumn{5}{|c|}{ Completion rates $(\%)$} \\
\hline Boys & 97 & 66 & 54 & 57 \\
\hline Girls & 94 & 71 & 64 & 58 \\
\hline \multicolumn{5}{|c|}{ Vertical drop (m) } \\
\hline Boys & 700 & 323 & 183 & \\
\hline Girls & 561 & 323 & 150 & \\
\hline
\end{tabular}

The number of competitors is indicated in parentheses. The number of runs in downhill includes two training competitions.

courses during the championship. Four injuries were recorded, all in girls $(\mathrm{p}<0.05)$ (table 1$)$. The injury rate was 4.0 per 1000 runs. An injury rate of 8.3 per 1000 runs was recorded in downhill. Placement of the gates along the course was as usual in international competitions, but on the first day of training in the downhill the last gate was difficult to pass. Many falls and one injury resulted. This gate was adjusted and the snow groomed all the way out to the nets; no further injury was recorded in this area. The injury recorded before adjustment of the gate was a multitrauma (ISS $=14$ ) including a brain concussion, a shoulder contusion, and an undislocated acetabular fracture. The other injuries recorded were only minor (ISS $=1$ ): one knee sprain (downhill training), one face contusion (downhill competition), and one shoulder contusion (giant slalom). The ISS sum for the whole championship was 17 , and the mean ISS was 4.25 per injury. A total of 573 racers completed the race $(57 \%)$, more girls $(58 \%)$ than boys $(57 \%)$ but the difference was not significant. Significant differences in race completion rates were found between the technical slalom and giant slalom races and the downhill race (table 2). A total of 141 racers did not finish the competition because of falls or technical difficulties (skiing errors). If the injury rate is related to this number, it amounts to 28.4 injuries per 1000 falls/skiing errors for all alpine disciplines. No relation between injury risk and FIS points was found in this championship. (FIS points is the standing of each racer according to performance in previous races.)

\section{Discussion}

The injury rate was higher (but not significantly so) in this championship (4.0 per 1000 runs) than in the alpine races of the 1994 Winter Olympic Games (1.9 per 1000 runs). ${ }^{12}$ When the injury rate was related to falls (skiing errors), no significant differences between the two competitions were observed. The number of injuries was small and all occurred in female skiers in both championships. This sex difference was significant $(\mathrm{p}<0.05)$. A higher injury rate has also been reported for female than male recreational skiers, but not when adjusted for skiing ability. The skiing ability of female racers was probably similar to that of male racers in the World Junior Championship, but differences in muscle strength, muscle recruitment order, and time to peak torque for hamstring contraction have been reported between male and female athletes. ${ }^{13}$ This may partially explain why female skiers suffered more injuries than male skiers, even though downhill courses for females are shorter than those for males. Higher injury rates have also been reported for females than males participating in other sports. ${ }^{14-16}$ Rupture of the anterior cruciate ligament is reported to be two to eight times more common in women participating in the same sports as men, presenting a sizeable health problem. A difference in anatomy between the sexes, resulting in differences in strength and flexibility, is probably one explanation..$^{17} 18$

An injury rate of 8.3 per 1000 runs was recorded in the downhill event (table 1). A higher injury rate in downhill than the other alpine disciplines has been reported previously. ${ }^{19-21}$ During the 1994 Winter Olympic Games, the injury rate in downhill was only 1.1 per 1000 runs. This is significantly lower $(p<0.05)$ than that of the Alpine World Junior Championship, but the number of injuries upon which this is based is low and the weather conditions and visibility were excellent during the 1994 Olympic Games. The total ISS was 17 and the mean ISS was 4.25 per injury in the Junior Championships; the respective values for the Winter Olympic Games were 17 and 5.6. The total ISS is useful when comparing one championship with another and gives a more realistic image of the injuries than just the number and the injury rate. The mean ISS recorded in this study is similar to that $(4.3$ per injury) for adolescent recreational skiers aged 15-19 in the Hafjell alpine area of Norway. ${ }^{22}$ Thus, the mean ISS for the championships was close to that for recreational skiers of the same age group. In both the Junior Championship and the Olympic Games, the ISS and injury rates were low, and we think this reflects efficient planning and preparation in both competitions. The injuries in the Junior Championship were not related to the FIS points, and this reflects the high performance of these junior athletes. The race completion rate in the Alpine World Junior Championship 
and the Winter Olympic Games were comparable (inside mean (2SD)), and no sex difference was recorded ${ }^{12}$ (table 2).

CONCLUSIONS

The injury rate for female competitors was significantly higher than for male competitors in both the 1995 Alpine World Junior Championship and the alpine disciplines of the 1994 Winter Olympic Games. Because of the high speed and risk, especially in downhill, juniors need the same safety measures along the slope and rescue services as Olympic racers. It is important that the safety arrangements are ready from the first day of training.

1 Shealy JE, Ettlinger CF. Gender-related injury patterns. In: Mote JR CD, Johnson R J, Hauser W, et al, eds. Skiing trauma and safety: tenth volume, ASTM STP 1266. Philadelphia: American Society for Testing and Materials, 1996:45phia:

2 Blitzer CM, Johnson RJ, Ettlinger CF, et al. Downhill skiing injuries in children. Am $\mathcal{F}$ Sports Med 1984;12:142-7.

3 Ekeland A, Holtemoen Å, Lystad H. Skiing injuries in alpine recreational skiers. In: Johnson RJ, Mote Jr CD, eds. Skiing recreational skiers. In: Johnson RJ, Mote Jr CD, eds. Sking 1022. Philadelphia: American Society for Testing and 1022. Philadelphia: A

4 Ellman BR, Holmes III EM, Jordan J, et al. Cruciate ligament injuries in female alpine ski racers. In: Johnson RJ Mote JR CD, Binet MH, eds. Skiing trauma and safety: 7th International Symposium, ASTM STP 1022. Philadelphia: American Society for Testing and Materials, 1989:105-11.

5 Ekeland A, Nordsletten L, Lystad H, et al. Previous skiing injuries in alpine Olympic racers. In: Johnson RJ, Mote JR $\mathrm{CD}$, Ekeland A, eds. Skiing trauma and safety: 11th International Symposium. Philadelphia: American Society for Testing and Materials, 1997:7-13

6 Federation Internationale de Ski (FIS) Medical Committee. Medical guide. Oberhofen: FIS, 1993.

7 Federation Internationale de Ski (FIS). Working Group Safety Experts. Oberhofen: FIS, 1991.

8 Bergstrøm KA, Askild O, Jørgensen NA, et al. Organization of skiing safety in a new alpine area. Injury Severity Score used to compare and classify the difficulty of the slopes. In: Johnson R J, Mote JR CD, eds. Skiing trauma and safety: 9th International Symposium, ASTM STP 1182. Philadelphia: American Society for Testing and Materials, 1993:229-35.

9 Committee on Injury Scaling. The Abbreviated Injury Scale, revision. Arlington Heights, IL: American Association of Automotive Medicine.

10 Baker SP, O'Neill B, Haddon W, et al. The Injury Severity Score: a method for describing patient with multiple injuries. F Trauma 1974;14:187-96.

11 Pillgram-Larsen J, Schistad P, Svennevig JL, et al. Triage. (In Norwegian.) Tidsskrift for Den norske Lageforen 1990; 110:1673-6.

12 Ekeland A, Dimmen S, Lystad H, et al. Completion rate and injuries in alpine races during the 1994 Olympic Winter Games. Scand f Med Sci Sports 1996;6:287-90.

13 Huston LJ, Wojtys E. Neuromuscular performance characteristics in elite female athletes. Am f Sports Med 1996;24: 427-36.

14 Arendt E, Dick R. Knee injury patterns among men and women in collegiate basketball and soccer. Am $\mathcal{F}$ Sports Med 1995;23:694-701.

15 Candy TA, Grana WA. Secondary school athletic injury in boys and girls. A three year comparision. Physician and Sportmedicine 1985;13:106-111.

16 Engström B, Johansson C, Tornkvist H. Soccer injuries among elite female players. Am F Sports Med 1991;19:3725.

17 Bjordal JM, Arnly F, Hannestad B, Strand T. Epidemiology of anterior cruciate ligament injuries in soccer. Am $\mathcal{F}$ Sports Med 1997;25:341-5.

18 Huston LJ, Greenfield ML, Wojtys EM. Anterior cruciate ligament injuries in the female athlete. Clin Orthop 2000;372:50-63.

19 Margreiter R, Raas E, Lugger LJ. The risk of injury in experienced alpine skiers. Clin Orthop North Am 1976;7:51-4.

20 Raas E. Some aspects of injuries in competitive skiers. In: Hauser W, Carlsson J, Magi M, ed. Ski trauma and skiing safety IV. Munich: TUEV, 1982:227-9.

21 Ekeland A, Holm A. Injury and race completion rates in alpine competitions. In: Johnson RJ, Mote JR CD, eds. Skiing trauma and safety: 5th International Symposium, ASTM STP 860. Philadelphia: American Society for Testing and STP 860. Philadelphia: Am
Materials, 1985:293-301.

22 Bergstrøm KA, Askild O, Jørgensen NA, et al. Evaluation of skiing injury by Injury Severity Score. Scand $\mathcal{F} \mathrm{Med} S \mathrm{Sci}$ Sports 1999;9:110-13.

23 Ueland Ø, Kopjar B. Occurrence and trends in ski injuries in Norway. Br f Sports Med 1998;32:299-303.

\section{Take home message}

Special attention should be paid to the safety of female competitors in downhill ski races.

Please note that the editorial office of British fournal of Sports Medicine has moved. Please send all future communications to: Dr Paul McCrory, British fournal of Sports Medicine, Centre for Sports Medicine Research \& Education School of Physiotherapy Level 1, 200 Berkeley Street, Parkville, Victoria 3052, Australia. Tel: +61 38344 4118; Fax: +61 383443771 ; Email: bjsm@bmjgroup.com 